\title{
СИСТЕМНІ ВІДНОШЕННЯ В ТЕМАТИЧНІЙ ГРУПІ ЛЕКСИКИ НА ПОЗНАЧЕННЯ ЛЮДИНИ ТА ЇЇ РИС У ГОВІРКАХ НИЖНЬОЇ НАДДНІПРЯНЩИНИ
}

Бойко Л. П., Сабліна С. В. Системні відношення в тематичній групі лексики на позначення людини та іiі рис у говірках Нижньої Наддніпрянщини.

У статті на діалектному матеріалі розглядається явище синонімії й варіантності в межах досліджуваної групи лексики, з'ясовується стилістичний потенціал позитивно й негативно маркованих лексем.

Ключові слова: синоніми, синонімічний ряд, негативне експресивне забарвлення, фонетичні варіанти, словотвірні варіанти, вторинна номінація.

Бойко Л. П., Саблина С. В. Системные связи в тематической группе лексики для обозначения человека и его черт в говорах Нижней Надднепрянщины.

В статье на материале диалектов рассматривается явление синонимии и вариантности в рамках анализированной группы лексики, изучается стилистический потенциал позитивно и негативно маркированных лексем.

Ключевые слова: синонимы, синонимический ряд, негативное експресивное употребление, фонетические варианты, словообразовательные варианты, вторичная номинация.

Boyko L. P., Sablina S. V. System relations in the thematic group of vocabulary is on denotation of man and its traits of the lower-Dnieper-steppe dialects.

The article deals with the phenomenon of synonymy and variation in the investigated lexics. Also stylistic potential of positive and negative marking lexems is cleared up.

Key words: synonyms, synonymic raw, negative expressive colouring, phonetic variants, word-building variants, secondary nomination.

Одна з визначальних властивостей говіркової лексичної системи - іiі експресивна насиченість. Експресивність діалектної лексики зумовлюється не тільки тим, хто і як, коли і для чого їі вживає, а й тим, хто, коли і як їі сприймає.

На думку В. Чабаненка, «різними ступенями експресивності говіркове слово може відзначатися лише тоді, коли воно семантично прозоре само по собі або коли таким його робить контекст. Звичайно, при цьому неабияку роль відіграють благозвучність, словотворча типовість 
діалектизму, а також, його здатність викликати певні естетичні й значеннєві асоціації» [5, с. 9].

Особливістю номінативної лексики на позначення людини та іiі рис $€$ те, що для більшості діалектних слів, уживаних для назв людей, характерна експресивність, емоційність, часте вираження оцінок об'єкта номінації.

Треба зазначити, що номінативні процеси в тематичній групі лексики на позначення людини та іiі рис відрізняються від тих, які виявляються в конкретно-предметній лексиці. Це пов'язано з яскравою експресивністю більшості діалектних слів, уживаних для номінації людини. Показниками експресивного забарвлення діалектної лексики зі значенням особи слід вважати використання слів у переносному значенні, наявністю тих чи тих елементів суб'єктивної оцінки тощо.

Лексика, пов'язана 3 людиною та іï рисами, уже студіювалася у працях 3. Бичка, Т. Вільчинської, Й. Дзендзелівського, К. Лук'янюк, В. Лєснової, А. Поповського та інших учених. Частково до аналізу залучався і матеріал говірок Нижньої Наддніпрянщини.

У діалектах, як зазначає С. Бевзенко, широко розвинута лексична синонімія, яка слугує «засобом вираження найрізноманітніших змістових, стилістичних та емоційних відтінків мовлення» [1, с. 192]. Яскравою ілюстрацією експресивної насиченості говіркової лексичної системи розгалуженими синонімічними рядами може бути лексика нижньонаддніпрянських говірок, яка використовується для номінації людини та їі рис.

Російський діалектолог О. Блінова свого часу аргументовано довела, що джерелами синонімії кожної окремої говірки є: літературна мова, мова усної народної поезії, материнські говірки (для території пізнього поселення), матеріал самої говірки. Дослідниця також зазначає, що внутрішньо діалектну синонімію живлять різноманітні запозичення: іншомовні, іншодіалектні, 3 літературної мови, міського просторіччя та 3 інших форм буття мови. Особливий інтерес викликає велика кількість вторинних назв у діалектах. Вторинні назви не свідчать про надлишковість діалектної лексичної системи, a $€$ продуктом живого мовлення й необхідні для задоволення вимог стилістичної виразності [2, с. 26]. Вторинна номінація містить оцінку позначуваного, яка в багатьох випадках залежить від ситуацій, дій, характеристик, що лежать в основі переосмислення мовних одиниць.

До складу тематичної групи лексики «Людина та ㄲï риси» входять різні лексико-семантичні групи: «зовнішній вигляд людини», «фізичний стан, психологічне сприйняття», «поведінка людини», «розумові здібності» «ставлення до праці» тощо. У кожній з цих груп спостерігаємо розгалужені синонімічні ряди.

У лексико-семантичній групі на позначення антропологічних особливостей людини, зокрема в межах підгрупи номенів для характеристики розміру та форми очей виявлений синонімічний ряд, до складу якого входять лексеми, об'єднані спільним лексичним значенням 
«людина з великими, опуклими очима»: булька́нь [6, с. 113] «той, що має великі очі»; булькатько́ [6, с. 113] «те саме, що булькань»; булько́ [6, с. 113] «те саме, що булькань»; окатько́ [8, с. 49] «те саме, що булькатько»; вилупа́нь [6, с. 154] «те саме, що булькатько».

Серед номінативних одиниць, що характеризують розмір та форму губ наявні такі синоніми: губатько́ [6, с. 255] «чоловік або хлопець із великими губами»; губа́ч [6, с. 255] «те саме, що губатько»; губошльо́n [6, с. 255] «чоловік або хлопець із великою; одвислою нижньою губою».

У межах підгрупи на позначення форми та розміру живота людини виявлений синонімічний ряд, складові якого об'єднані спільним лексичним значенням «людина з великим животом»: глади́чій [6, с. 232] «пузанько, черевань»; пузанько́ [8, с. 297] «пузань»; пузатько́ [8, с. 297] «те саме, що пузанько»; пуза́ч [8, с. 297] «те саме, що пузанько»; брюха́ч [6, с. 108] «черевань, гладун»; бруха́ч [6, с. 108] «черевань»; лева́да [7, с. 246] «дуже гладкий, з великим животом чоловік». Такі синонімічні ряди нечисленні, проте більшість їх складників містить у собі велику силу експресії.

У лексико-семантичній групі слів, що вживаються для характеристики антропологічних особливостей людини, переважають номінативні одиниці, які містять негативне забарвлення. Залежно від ступеня експресивної насиченості номени можуть мати забарвлення лайливе, глузливе, насмішкувате, іронічне, жартівливе тощо. Наприклад, група лексем для характеристики зросту людини представлена в обстеженому матеріалі такими стилістично маркованими номінативними одиницями, як: го́йда [6, с. 239] ірон. «висока жінка або дівчина»; коби́ла [7, с. 180] лайл. «висока, нестатурна й апатична людина»; я'щірка [9, с. 261] перен., глузл. «про надмірно худу, тонку жінку чи дівчину»; таве́ля [6, с. 212] ірон. «висока і худа дівчина або жінка»; верли́та [6, с. 135] «високий худий чоловік, хлопець»; довга́ч [6, с. 281] «високий, худий чоловік»; довге́ля [6, с. 281] «висока людина» тощо тощо. Серед виявлених лексем зафіксовані такі, що виникли внаслідок вторинної номінації: верба́ [6, с. 133] перен., ірон. «людина високого зросту»; я'щірка [9, с. 264] перен., глузл. «про надмірно худу, тонку жінку чи дівчину»; шво́рка [9, с. 231] перен., ірон. «дуже худа і висока жінка / дівчина». Такі номени утворилися в результаті перенесення на людину ознак тварин i властивостей рослин.

Як зазначає В. Чабаненко, варіантність лексем складає вагомий елемент виражально-зображальних мовних засобів [5, с. 62]. Яскравою ілюстрацією стилістичних можливостей варіантів може бути лексика нижньонаддніпрянських говірок, що використовується для номінації людини та іï рис. Комбіновані варіанти слів утворюють пари, які становлять безперечний унікум у системі виражально-зображальних засобів української мови. Виразова цінність варіантів обумовлюється тим, що вони містять в собі експресію, а більшість 3 них $є$ стилістично 
маркованими. Наприклад, у межах групи слів для характеристики кольору й стану волосся трапляються такі варіанти, як: замазю'ка [6, с. 49] «замазура» і замазьо́ха [7, с. 50] зневажл. «те саме, що замазюка»; кочма́н [6, с. 208] «чоловік із розкудланим волоссям» і кучма́н [7, с. 208] «те саме, що кочман». Серед лексем для характеристики конфігурації тіла людини виявлені такі варіанти: дохляк [6, с. 291] зневажл. «дуже худий чоловік, хлопець» і здохляк [7, с. 99] зневажл. «дуже худий, виснажений чоловік / хлопець». Група номенів для характеристики зросту людини також має у своєму складі варіанти: вергела́ [6, с.134] ірон. «дуже високий чоловік або юнак», вергеля'ка [6, с.134] ірон. збільш.-згруб. до вергела, вергеляра [6, с. 134] ірон. те саме, що вергеляка і верге́ля [6, с. 134] ірон. «дуже висока жінка або дівчина».

У межах підгрупи номенів для негативної характеристики розумових здібностей людини зафіксований синонімічний ряд, до складу якого входять лексеми, об'єднані спільним лексичним значенням «дурна людина»: дурнопльо́m [6, с. 304] «дурень, пустомеля»; сапето́н [9, с. 55] «дурник, недоумкувата людина»; непоніма́ющий [7, с. 364] «слабий розумом, темний»; дурбе́й [6, с. 303] «дурень»; дурко́ [6, с. 304] «те саме, що дурбей»; дуронда́ [6, с. 305] «те саме, що дурбей»; дурма́н [6, с. 304] «те саме, що дурбей»; дуриле́й [6, с. 304] «те саме, що дурбей»; дурноколінко [6, с. 304] «те саме, що дурбей»; дурноколінний [6, с. 304] «придуркуватий»; дурнопльо́m [6, с. 304] «дурень, пустомеля»; довбурь [6, с. 281] «телепень»; ве́ва [6, с. 132] «дурень, телепень»; бе́лебень $[6$, c. 76] «дурень». Остання лексема ряду містить у собі найбільший ступінь негативного емоційно-експресивного забарвлення.

Уживання антонімічних лексем у межах цієї ж підгрупи сприяє яскравій експресивній насиченості номенів і супроводжується певним емоційно-експресивним забарвленням, як-от: форкува́тий [9, с. 186] «розумний, розсудливий»; самостоя'тільний [9, с. 54] «розсудливий, тверезо мислячий»; знаюка [7, с. 111] «знайко, вчений»; доріча́ний [6, с. 289] «такий, що все говорить до діла, доречно; розумний» тощо.

Для характеристики скупої людини зафіксований синонімічний ряд, до складу якого входять лексеми, об'єднані спільним лексичним значенням «скупа людина»: кандибе́й [7, с. 146] «скнара»; жадю'га [6, с. 309] «жадібна людина»; жада́к [6, с. 308] «жадібна, зажерлива, сильно бажаюча людина»; скес [9, с. 71] зневажл. «жаднюга, скупиндя»; жадню'к [6, с. 308] «жаднюга»; жадню'ка [6, с. 308] «те саме, що жаднюг»; жадню'чка [6, с. 308] зневажл. «зменшене до жаднюка»; скупірдя'й [9, с. 78] «скупердяй». Остання лексема ряду несе в собі найбільше негативне емоційно-експресивне навантаження. Виявлені синоніми цієї лексико-семантичної групи містять у собі велику силу експресії.

У межах лексико-семантичної групи для характеристики сфери психічної діяльності людини кількісно переважають номени негативного 
емоційно-експресивного забарвлення. У зв'язку з цим маркованість розглядуваних номенів така: іронічне, зневажливе, лайливе тощо. Наприклад, група лексем для характеристики злої, жорстокої людини представлена в обстеженому матеріалі такими стилістично маркованими номінативними одиницями, як: зара́зький [7, с. 66] лайл. «капосний, негідний, поганий»; озія' [8, с. 46] зневажл. «зла, сварлива жінка чи дівчина»; добря'ка [6, с. 281] ірон. «погана, підступна, зла людина»; га́гра [6, с. 213] зневажл. «зла жінка»; товаря'ка [9, с. 126] лайл. «безсердечна, жорстока людина»; ія [7, с. 133] зневажл. «зла жінка» тощо. Серед виявлених лексем зафіксовані такі, що виникли внаслідок вторинної номінації: чумá [9, с. 223] перен., лайл. «погана, зла людина»; дереви́на [6, с. 263] перен. «байдужа, жорстока, безсердечна людина»; дерев'яний [6, с. 263] «байдужий, бездушний, жорстокий».

Словотвірні варіанти лексем, як вагомий елемент виражальнозображальних засобів у групі найменувань, що вживаються для характеристики злої, брехливої людини, репрезентовані такими номінативними одиницями: хитрюга́н [9, с. 194] Зневажл. «хитрюга»; хитрю'к [9, с.194] зневажл. «те саме, що хитрюган»; бреха́рь [6, с.103] «брехун»; брехло́ [6, с. 103] «те саме, що брехарь»; брехуня'ка [6, с.104] «великий брехун»; брехуня' ра [6, с. 104] «те саме, що брехуняка».

У межах лексико-семантичної групи на позначення соціальнотрудових стосунків людини окремі номінативні одиниці вступають у синонімічні зв'язки. Так, у підгрупі номенів, що вживаються для характеристики людини, схильної до скоєння злочину, виявлений синонімічний ряд, лексеми якого об'єднані спільним лексичним значенням «злодій»: вор [6, с. 196] «злодій»; ворю'га [6, с. 198] «збільшене до вор»; ворю'ка [6, с. 198] «те саме, що ворюга»; воря'ка [6, с. 198] «те саме, що ворюга» тощо. Серед номінативних одиниць, які характеризують ставлення людини до праці, зафіксовані такі синоніми, як: ло́дарь [7, с. 258] «ледар»; ло́дарька [7, с. 258] «жіноче до лодарь»; леда́берня [7, с. 247] «ледарка»; лежню'га [7, с. 248] «те саме, що ледаберня»; байдала́ [6, с. 58] «нероба, ледар»; ле́йба [7, с. 248] «ледар, лежебока»; гультя' га [6, с. 257] «нероба, ледащо»; багла́й [6, с. 55] «ледар, ледащо».

У межах підгрупи номенів для характеристики балакучої людини виявлений синонімічний ряд, лексеми якого об’єднані спільним лексичним значенням «людина, яка багато говорить»: балабо́лка $[6$, с. 60] «базіка»; баля'ба [6, с. 61] «те саме, що й балаболка»; балабо́лочка [6, с. 60] «зменшене до балаболка»; баля'бочка [6, с. 61] «зменшене до баляба»; балабо́н [6, с. 60] «базікало»; балабо́нчик [6, с. 60] «зменшене до балабон»; торохті́лка [9, с. 129] «балакуха»; торохтьо́лка [9, с. 130] «ірон. те саме, що торохтілка»; mpenýxa [9, с. 133] «те саме, що торохтілка»; торохти́ха [9, с. 130] «балакуха»; торохту́шка [9, с. 130] «те саме, що торохтуха». Треба зазначити, що серед аналізованої лексико-семантичної групи 
кількісно переважають номени, які мають виразно негативну семантику. У підгрупі номінативних одиниць для характеристики бешкетних, жвавих людей виявлені лексеми, які утворилися внаслідок вторинної номінації: же́вчик [6, с. 311] перен. «жвавий вертлявий хлопчик»; ко́ник [7, с. 197] перен. фам. «швидка, надто рухлива людина».

Оскільки однією 3 найхарактерніших особливостей діалектної лексики є їі стилістична виразність, експресивність, то серед номінативних одиниць для характеристики людей, які вживають алкогольні напої, були виявлені такі стилістично марковані лексеми, як: n'яндали́га [8, с. 302] зневажл. «П'яниця»; n'янди́жка [8, с. 303] «те саме, що п'яндига»; алкана́вm [6, с. 49] жарт., «П’яниця, алкоголік»; ярипе́ник [9, с. 258] зневажл. «П’яниця»; бормото́лог [6, с. 98] жарт., «П’яниця, алкоголік»; камка́pь [7, с. 144] ірон. «п’яниця» тощо. Серед номенів, які позначають аморальну поведінку чоловіка / жінки, трапляються численні стилістично марковані лексеми, наприклад: бабоню' $x$ [6, с. 54] зневажл. «ловелас»; розтя'ганий [9, с. 41] вульг. «розбещений позашлюбними зв'язками»; ля'рва [7, с. 264] лайл. «пройда, жінка легкої поведінки»; поволо́ка [8, с. 140] зневажл. «повія»; шве́ндялка [9, с. 230] ірон. «швендя» тощо.

Стилістично виразними в лексико-семантичній групі на позначення соціально-трудових стосунків людини є словотвірні варіанти в межах підгрупи лексем, які характеризують бешкетних, жвавих людей: крикуня'ка [7, с. 216] збільш. «крикун» і крикуня'ра [7, с. 217] «те саме, що крикуняка». У семантику останньої лексеми суфікс -яр- вносить додатковий відтінок згрубілості. Виразно стилістичні фонетичні варіанти виявлені також і в підгрупі для характеристики людини, що вживає алкогольні напої: алкана́вm [6, с. 49] жарт. «п’яниця, алкоголік» і алкона́вт [6, с. 49] жарт. «те саме, що алканавт»; n'яндали́га [8, с. 302] зневажл. «п'яниця» і $n$ 'яндили́га [8, с. 303] зневажл. «те саме, що п’яндалига». У підгрупі номінативних одиниць на позначення людей, схильних до скоєння злочину, зафіксовані такі приклади фонетичних варіантів: заріза́ка [7, с. 67] «убивця, розбійник» i зарізя'ка [7, с. 68] фам. «те саме, що зарізака». Більшість виявлених фонетичних варіантів містить у собі негативну експресію і є стилістично маркованими.

У межах підгрупи номенів для характеристики хворих, слабких людей виявлений синонімічний ряд, лексеми якого об'єднані спільним лексичним значенням «хвора людина»: больни́ŭ [6, с. 95] «хворий»; благи́ŭ [6, с. 87] «хворий»; доходни́ŭ [6, с. 291] «виснажений, слабосилий»; доходя'zа [6, с. 292] «виснажена, тяжко хвора, слабосила людина» тощо. Остання лексема в синонімічному ряді має найекспресивніше забарвлення. Серед лексем підгрупи для характеристики дефектів мовлення людини зафіксовані такі синоніми, як: затина́ка [7, с. 77] «заїка»; зазі́ка [7, с. 29] «заїка»; папаїкка [8, с. 73] «заїка». Остання лексема в поданому синонімічному ряді має негативне експресивне забарвлення. Виявлені 
синонімічні ряди є нечисленними, але переважна більшість лексем містить у собі велику силу експресії, образності.

Підгрупа лексем на позначення поняття «глуха людина» репрезентована у поданому матеріалі такими стилістично маркованими варіантами, як: глу́хман [6, с. 235] зневажл. «глушман»; глухма́p [6, с. 235] зневажл. «те саме, що глушман»; глушпа́ [6, с. 236] зневажл. «те саме, що глухар»; глушпа́к [6, с. 236] зневажл. «те саме, що глушпа»; глушпе́m [6, с. 236] зневажл. «те саме, що глушпак»; глушпе́ma [6, с. 236] зневажл. «те саме, що глушпет».

Можна зробити висновок про те, що аналізована тематична група в досліджуваних говірках складається 3 багатьох синонімічних гнізд i гетеронімних рядів, які здебільшого репрезентують семами, пов'язані із зовнішніми і внутрішніми рисами людини. Абсолютна більшість лексики стилістично маркована. До вторинної номінації вдаються переважно при негативній характеристиці людини.

\section{Література}

1. Бевзенко С. П. Українська діалектологія : [підручник] / С. П. Бевзенко. - К.: Вища школа, 1980. - 245 с.

2. Блинова О. И. Проблемы диалектологической лексикологии : автореф. дисс. на соискание доктора филол. наук : спец. 10.02 .01 «Русский язык» / О. И. Блинова - Саратов, 1975. - 44 с.

3. Вовк О. Б. Семантична структура образної номінації / О. Б. Вовк // Мовознавство. - 1985. - № 5. - С. 64 -68.

4. Українська літературна мова в її взаємодії з територіальними діалектами : [зб. статей]. - К. : Наукова думка, 1977. - 243 с.

5. Чабаненко В. А. Стилістика експресивних засобів української мови : [монографія]. - Ч. 3 / В. А. Чабаненко. - Запоріжжя : ЗДУ, 1996. - 126 с.

6. Чабаненко В. А. Словник говірок Нижньої Наддніпрянщини : у 4-х т. / В. А. Чабаненко. Запоріжжя : ВПК Запоріжжя, 1992. - Т. 1.- 1992. - 324 с.

7. Чабаненко В. А. Словник говірок Нижньої Наддніпрянщини : у 4-х т. / В. А. Чабаненко. Запоріжжя : ВПК Запоріжжя, 1992. - Т. 2.- 1992. - 371 с.

8. Чабаненко В. А. Словник говірок Нижньої Наддніпрянщини : у 4-х т. / В. А. Чабаненко. Запоріжжя : ВПК Запоріжжя, 1992. - Т. 3.- 1992. - 303 с.

9. Чабаненко В. А. Словник говірок Нижньої Наддніпрянщини : у 4-х т. / В. А. Чабаненко. Запоріжжя : ВПК Запоріжжя, 1992. - Т. 4.- 1992. - 260 с. 